\title{
Obstacles open the door - Negative shocks can motivate individuals to focus on opportunities
}

\author{
Jin Feng, Wenxia Zhou, Shuoyu Li and Mengyi Li (D)
}

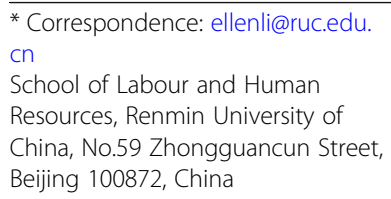

* Correspondence: ellenli@ruc.edu. cn

School of Labour and Human Resources, Renmin University of China, No.59 Zhongguancun Street, Beijing 100872, China

\begin{abstract}
By responding to the call for research on negative career shocks and future time perspective, this study regarded internal social capital as a tool of resource retention which shifts attention to negative career shocks' positive effects. We test a moderated mediation model which illustrates the effect of negative career shocks on focus on opportunities - positive dimension of occupational future time perspective. Results revealed that internal social capital acts as the mediator between negative career shocks and focus on opportunities, and organizational embeddedness moderats the mediation effect. The relationship is stronger when individuals are highly embedded in organizations.
\end{abstract}

Keywords: Career shocks, Future time perspective, Focus on opportunities, Internal social capital, Organizational embeddedness

"Whatever does not kill them makes them stronger. - - Friedrich Nietzsche"

"Trouble is only opportunity in work clothes. - - Henry J. Kaiser"

Recent career research has argued that career development is becoming more dynamic, complex, unpredictable and flexible (Vuori and Okkonen 2012; Baruch 2004). The increasingly complex and unpredictable nature of contemporary careers will be accompanied by increased unpredictable career events such as layoffs, bankruptcy or family issues that may change individual's career path. In research, these events are represented by terms such as happenstance, serendipity, or chance events (Miller 1983; Betsworth and Hansen 1996; Bright et al. 2005; Akkermans et al. 2018). Hirschi (2010) indicates that such major events that happen in people's lives have a significant impact on their career paths. Shocks (e.g. an important mentor or colleague's departure or organizational change) have been shown to predict organizational turnover (Hom et al. 2017; Lee et al. 2017; Seibert et al. 2013), and better clarify why people leave or stay.

Lee and Mitchell (1994) proposed career shock as a jarring event that evokes a person to pause and think about the meaning of their jobs and in turn, provokes some considerations of leaving their jobs. Recently, Akkermans et al. (2018) described career shock as a disruptive and extraordinary event. Shocks can be positive, neutral or

(c) The Author(s). 2019 Open Access This article is distributed under the terms of the Creative Commons Attribution 4.0 International License (http://creativecommons.org/licenses/by/4.0/), which permits unrestricted use, distribution, and reproduction in any medium, provided you give appropriate credit to the original author(s) and the source, provide a link to the Creative Commons license, and indicate if changes were made. 
negative, expected or unexpected, and personal or organizational (Holtom et al. 2005). As one of the most important factors predicting employees' voluntary turnover, career shock has been proven to influence individuals' work behaviors and career planning (Burton et al. 2010; Holtom et al. 2005), and alter employee's career path (Bright et al. 2005). However, not enough attention has been paid to individual career trajectories in this (Akkermans et al. 2018). Hence, investigating the role of career shocks on individuals' career decision-making can help organizations to predict work behaviors such as work engagement, performance, and turnover.

Future time perspective is a core construct in socioemotional selectivity theory (Carstensen et al. 1999), and is defined as an individual's "subjective sense of future time" (Carstensen, 2006). From socioemotional selectivity theory, age is the major factor to predict future time perspective (Fung et al. 2001), and younger adults focus more on opportunities compared to older adults (Zacher \& de Lange, 2011). Occupational future time perspective is conceptually distinguished in two related dimensions, "perceived remaining time" and "focus on opportunities." Perceived remaining time is defined as individuals' perception of restrictions in future career and concentration on losses and limitations. Focus on opportunities is defined as individuals' perceptions of new work-related goals and possibilities that are foreseen in the future (Zacher and Frese, 2009). Researchers have supported the relationship between occupational future time perspective and job related outcomes, such as career maturity, career planning and career decidedness (e.g. Taber and Blankemeyer 2015). The way how individuals perceive their future can influence their career decisions, career maturity (Cheng et al. 2016), job satisfaction (Weikamp and Göritz 2016), occupational self-efficacy, career commitment and turnover intention (Park and Jung 2015). However, there is a lack of research in how constraining job factors such as negative life events and hindering job demands impact employees' future time perspective (Rudolph et al., 2018). Examining and discussing constraining job factors as antecedents can enrich the understanding of future time perspective.

Our study aims to examine the effect of negative career shocks for three reasons. First, in daily life, people believe that the more positive life events, the better. However events evoke different emotional intensities, so more may not always be better (Seta et al. 2008). Researchers suggest that "bad is better than good," and suggest that negative events may exert stronger influence on individual's career development by providing greater motivation compared with positive events (Baumeister et al. 2001; Larsen and Ketelaar 1991; Holtom et al. 2012). Second, previous research indicates that, due to the effect of mood, each person can react differently towards negative shocks (Weiss and Cropanzano 1996), so that rather than reducing work effort, highly embedded employees are possible to re-focus on the job and increase organizational citizenship behavior (OCB) after experiencing negative shocks (Burton et al. 2010). Last but not least, negative shocks appear more often than positive shocks (Holtom et al. 2012). People may not be sensitive to positive shocks, but are sensitive to negative shocks. Therefore, discovering the effects of negative shocks can advance the research and theory in career development.

Exploring the predictors of both dimensions of occupational future time perspective is very important (Henry et al., 2017; Rudolph et al. 2018). However, the predictors of focus on opportunities are lacking in current research. Job complexity and job control 
are the main antecedents that has been studied so far (Zacher and Frese 2009, 2011; Rudolph et al. 2018). In order to find the antecedents of focus on opportunities, we proposed and tested a moderated mediation model in which we posit that negative shocks indirectly influences people' s future time perspective through the effect of social capital, and organizational embeddedness acts as a boundary condition of this relationship. Fig. 1 presents our proposed research model.

\section{Conceptual development and hypotheses development}

The unfolding model of voluntary employee turnover (Lee and Mitchell 1994; Lee et al. 1996) proposed the construct of career shock from Beach's (1990) decision-making model and image theory, to understand the processes of employees' decisions to quit. According to the image theory, individuals constantly obtain information that could potentially lead to changes in their behavior. Some sorts of unexpected events, which have been defined as shocks to the system, lead individuals to pause and think about the meaning or implication in relation to their job (Lee and Mitchell 1994). Based on this unfolding model of voluntary employee turnover, shocks can alter individuals' psychological processes. If it recalls prior memory and violates individuals' value image, then people would choose a preexisting plan to leave. Seibert et al. (2013) showed that positive shocks instead of negative shocks can motivate individuals to pursue to graduate education, which helps to understand the benefits of shocks. Also, job embeddedness has been proven to buffer the negative effect of negative shocks during the workplace (Holtom and Inderrieden 2006; Burton et al., 2010; Holtom et al. 2012). These studies enable us to analyze the benefits of negative shocks and address the research question: How can negative shocks motivate employees?

Hobfoll's $(1988,1989)$ model of conservation of resources proposes that individuals strive to retain, protect, and build resources, and then apply them to improve wellbeing and personal development over time. Resources are defined as assets and goods that people value, with an emphasis on objects, states, and conditions; almost anything good can be considered a resource (Gorgievski et al. 2011). Job security (Selenko et al. 2013), autonomy (Chen et al. 2009), social support (Zimmermann et al. 2011; Liu et al. 2013; Diestel and Schmidt 2012), self-esteem, self-efficacy, locus of control, and core self-evaluation (Chen et al., 2009; Xanthopoulou et al., 2009) are examples of psychological resources reported in the organizational literature. Therefore, to open the black box of negative shocks' impact, resource loss and retrieval can be considered as critical for analyzing the psychological process.

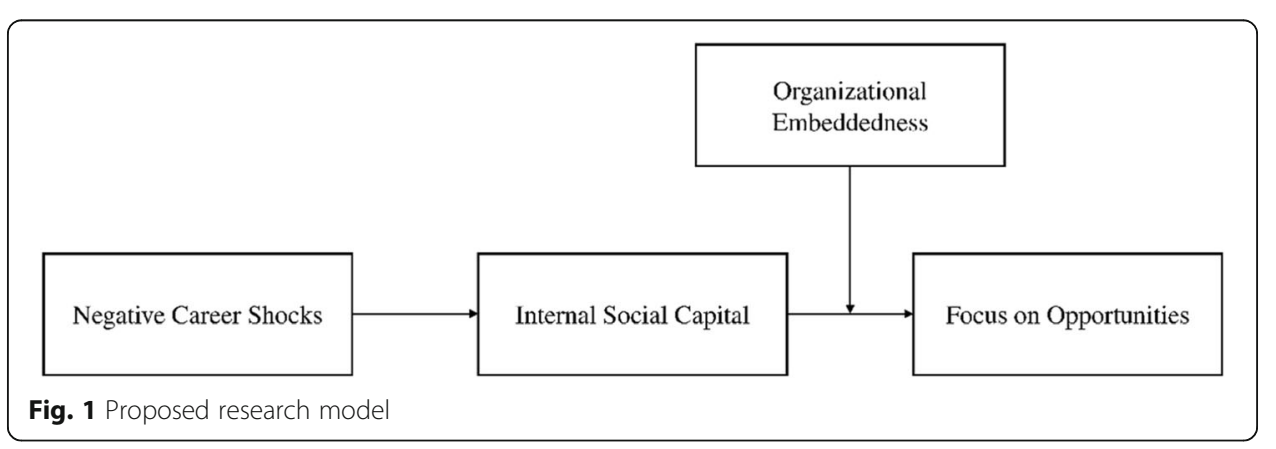




\section{Mediating influence of internal social capital}

When people experience negative shocks which threaten their resources and diminish their well-being, they are likely to have a sense of insecurity and lack of support, making people feel that they lose important psychological resources (Koopmann et al., 2016). According to conservation of resources theory, in the face of stressful resource loss, individuals may use other resources to offset net loss and attempt to conserve remaining resources (cf. Pearlin et al. 1981; Halbesleben 2010; Halbesleben and Wheeler 2011). An effective strategy to mitigate the situation is very important to one's career path. During career shocks, social capital provides an effective way to shift attention to career management strategies (Seibert et al. 2001; Wayne et al. 1999). Social capital can be used to help employees find new job alternatives or positions both inside and outside the organization (Granovetter, 1973; Marsden \& Hurlbert, 1988; Zippay, 2001).

The construct of internal social capital is a critical dimension of political skill and refers to developing and using networks of people (Ferris et al. 2005). It mainly indicates establishment of social ties within the organization, especially among supervisors or managers, and advances career success inside the company. Individuals with high level of internal social capital easily develop friendship and build strong and beneficial alliances and coalitions. They ensure that they are well positioned in order to both create and take advantage of opportunities (Pfeffer 1992). Through internal social capital, people retain, protect, and build valued social capital resources by developing relationships with others who have the potential to assist them in their careers (Forret and Dougherty 2004). Therefore, internal social capital can meet individuals' needs and serve as intrinsic motivation to achieve their innate goal. In this paper, internal social capital is considered as resources in Hobfoll's model (Hobfoll 1988, 1989).

When individuals have more friends and build good relationship with influential colleagues through internal social capital, they gain social support (Diestel and Schmidt 2012) and build a resource-rich environment beneficial for career development. Social support has been shown to be an effective strategy to deal with stressful life events, and close dyadic relationships offer well-established psychological benefits (Collins and Feeney 2000), which protect individuals' valued identities (Petriglieri, 2011) and strengthen their career goals. This reasoning is in line with the process known as a "gain cycle" from the conservation of resources model (Hobfoll 1989). Based on the social support in the work environment, individuals would be better able to predict their future career development. The more resource-rich the work environment, the more opportunities an individual perceives for their future work (Rudolph et al. 2018). Therefore, we propose that:

Hypothesis 1: Internal social capital mediates the relationship between negative shocks and focus on opportunities.

\section{Moderating influence of organizational Embeddedness}

Mitchell et al. (2001) used three dimensions for job embeddedness: links, fit and sacrifice. Links describes the number of ties employees have within the organization, i.e., the formal or informal connections between a person and institutions or other people. Fit means the compatibility or comfort between employees and the organization, or environment. While 
sacrifice stands for the potential cost or benefits of leaving the job, this construct has later been developed more broadly to indicate organizational and community embeddedness (Ng and Feldman 2010a). Crossley et al. (2007) proposed a reflective measure for job embeddedness which has better psychometric properties, as a measure for organizational embeddedness. This measure has equivalent prediction in comparison with the original one (Lee et al., 2014), and has been adopted to predict social capital and human capital (Ng and Feldman 2010a).

Studies show that organizational identification has a positive influence on individuals' emotions (Avanzi et al. 2015; Avanzi et al. 2018; Frisch et al. 2014), and on turnover (e.g. Van Dick et al. 2004; Lee et al. 2015). However, as we concentrate on the adverse impact of negative career shocks and organizational embeddedness has shown to have a buffer effect (Burton et al. 2010; Holtom et al. 2012), we decide to include organizational embeddedness in our model.

Organizational embeddedness represents a broad constellation of influences on employee retention (Lee et al. 2014; Mitchell et.al., 2001). In this study, we focus on organizational embeddedness that is more closely related to individuals' career development, and it shows a strong link between career plans and the present job (Ng \& Feldman, 2010a). Employees who are highly embedded in organizations will have more job security, employment stability and professional success (Ng and Feldman 2007) and reduced likelihood of looking for alternative jobs (Holtom and Inderrieden 2006). In order to reduce the negative influence of turnover, researchers study the buffer effect of organizational embeddedness (Holtom and Inderrieden 2006; Burton et al. 2010; Holtom et al. 2012). Therefore, high level of organizational embeddedness could help to reduce turnover and turnover intention, or improve job related outcomes such as core task performance and citizenship behaviors (Crossley et al. 2007; Wijayanto and Kismono 2004).

From the escalation of commitment literature (Brockner 1992; Staw 1981), highly embedded individuals will continue to exert efforts, increase their efforts to cement their relationship with the organization even under negative shocks (Burton et al. 2010). Highly embedded individuals tend to set goals within their organizations, are motivated to stay and work in their organizations, and have a high degree of fit with their organization. Thus, these individuals have a higher degree of interconnectedness with their peers, and more social capital leading to increase in focus on opportunities. In addition, when individuals develop a high degree of fit with their organizations and perceive higher cost of leaving, they may be motivated to deploy skills that could help them stay, and therefore reduce the effect of negative shocks and shift the attention to opportunities.

Hypothesis 2 : Organizational embeddedness moderates the strength of the mediated relationship between negative shocks and focus on opportunities through internal social capital such that the mediated relationship is stronger when organizational embeddedness is high.

Hypothesis 3 : Organizational embeddedness moderates the strength of the mediated relationship between negative shocks and focus on opportunities through internal social capital such that the mediated relationship is weaker when organizational embeddedness is low. 


\section{Method}

\section{Sample and procedure}

We conducted a time-lagged study in which we collected two-wave data in June (wave 1) and December (wave 2) 2018. In wave 1 (T1) we measured negative career shocks and demographic varibles, and in wave 2 (T2) we measured internal social capital, organizational embeddedness and occupational future time perspective. Since we were interested in career shocks and future time perspective of general population in China, we avoided collecting data within companies in case to obtain a biased sample. Instead, we used a snowball sampling method through a Chinese social network App (Wechat). Wechat was created in 2011 by a Chinese Internet giant Tencent as a chat App with features and functionality similar to WhatsApp. According to Wechat data report (2018, released by Wechat official), about 1.08 billion of which 63 million were over 55 years old are monthly active users of Wechat.

We received a total of 352 responses in T1. Each participant received RMB5 for participation. Six months later, the T2 survey invitation was sent to same participants, each participant receive another RMB5 as gratitude. After matching the telephone number, email address and name, our samples contained 230 participants. In order to ensure the quality of survey, we set three testing questions in both surveys which were "if you are answering the questions carefully, please choose 5 (strongly agree)" "if you are answering the questions carefully, please choose 4 (relatively agree)" and "if you are answering the questions carefully, please choose 3 (sometimes)." 20 responses that failed these testing questions were eliminated and the final sample size was 210 .

Average age was 31.48 years old $(S D=5.63)$ and $31.80 \%$ of them were female. Average tenure with the current employer was 8.10 years $(\mathrm{SD}=6.09)$. The participants worked in varied organizations such as state-owned enterprises (23.20\%), party and government organizations or public institutions $(22.70 \%)$, private enterprises $(19.10 \%)$, institutions of higher learning (15.00\%), foreign-owned enterprises $(8.60 \%)$, strategic response unit (2.30\%) among others (9.10\%). 56.80\% of the participants in our sample had a bachelor degree, $28.60 \%$ had a master degree, $5.90 \%$ had a doctor degree, still $8.60 \%$ among others.

\section{Measures}

\section{Negative career shocks}

We use the career shocks scale developed by Seibert et al. (2013) mainly because this scale was specifically related to individual's career management. The scale contains four items to measure both positive shocks and negative shocks. In this study, since we only focus on negative shocks, only the two items about negative career shocks were used (see Appendix). Participants were asked whether they experienced the career shock or not (coded as 1 or 0 ), since a career shock is a formal construct that implies employees' turnover intention. In order to test the validity, we conducted the regression effect on participants' turnover intention $(\beta=0.47, p<0.01)$. The result supported the use of this measure for career shocks by definition and in accordance with previous research.

\section{Internal social capital}

We used three items out of the six items from the Political Skill Inventory which is measured on a 5 -point Likert-format scale (from $1=$ strongly disagree to $5=$ strongly 
agree) (Ferris et al. 2005). Before the wave 1 survey (T1), we pruned several items to simplify our questionnaire. As a result, we used three high loading items to measure internal social capital (see Apendix). The Cronbach's $\alpha$ was acceptable at 0.71 .

\section{Organizational embeddedness}

We used the global organizational embeddedness scale (Crossley et al. 2007) (see Appendix). The original scale consisted of seven items, we deleted one item ("I feel tied to this organization") for semantic repetition with other items such as "I am tightly connected to this organization". All items were measured on a 5-point Likert scale (from $1=$ strongly disagree to $5=$ strongly agree). This scale had an acceptable reliability of 0.76 .

\section{Focus on opportunities}

We measured focus on opportunities with three items from Zacher and Frese's (2009) occupational future time perspective scale (see Appendix). Participants were asked to rate on a 5 -point scale (from $1=$ strongly disagree to $5=$ strongly agree) with a Cronbach's $\alpha=0.75$. Some researchers found that perceived remaining time may be an antecedent of focus on opportunities (Kooij et al. 2014). In addition, perceived remaining time and focus on opportunities were counterparts, so in this study we controlled for the effect of perceived remaining time (see Appendix). To test whether perceived remaining time and focus on opportunities were two distinct dimensions, we conducted confirmatory factor analyses (CFA) comparing results of one-factor and two-factor model. The two-factor model fit the dataset better, with $\chi^{2} / d f=1.49$, TLI $=0.95$, CFI $=$ 0.97 , RMSEA $=0.05$, SRMR $=0.03$. This result indicated that the two dimensions should be distinguished.

\section{Control variables}

Individual characteristics are important sources of occupational future time perspective (for a review see Kooij et al. 2018; Rudolph et al. 2018). Among all the antecedents of occupational future time perspective, age was highly important (Froehlich et al. 2016; Zacher and Frese 2009). Because people in different life stages have different perceptions of time and this would end up in various perspectives about future (Lang and Carstensen 2002), in this study we controlled for demographic characteristics such as gender, age, organizational tenure and education. Other demographic characteristics such as company size and company type were not controlled because they were not personal resources or time-related characteristics.

\section{Data analysis}

We used SPSS 22.0 to conduct descriptive statistics and correlation analysis. Before testing the hypotheses and the model, CFA was conducted using Mplus 7.0. In order to test indirect effects, Preacher and Hayes (2004) recommended a resampling method such as bootstrapping to increase power and decrease Type I error. We performed bootstrapping using Model 14 of Process bootstrapping approach provided by Hayes (http://www.afhayes.com/spss-sasand-mplus-macros-and-code. html) to test direct, indirect, and moderated mediation model. 


\section{Results}

\section{Descriptive statistics and correlations}

Table 1 presented the means, standard deviations and correlations for main variables. We found that negative career shocks were positively related with focus on opportunities $(r=0.16, p<0.05)$ and internal social capital $(r=0.19, p<0.01)$. Internal social capital was positively related with focus on opportunities $(r=0.27, p<0.001)$. Organizational embeddedness was not significantly related with focus on opportunities $(r=-0.13, p>0.05)$. Finally, the results showed internal social capital had a stronger relation with focus on opportunities compared with other factors.

\section{Confirmatory factor analysis}

CFA was used to test discriminant validity of the multi-dimension scale (internal social capital, organizational embeddedness and focus on opportunities). Before CFA, we conducted the Kaiser-Meyer-Olkin (KMO) test and the Bartlett's test of sphericity. The KMO value of 0.72 and the result of Bartlett's test sphericity ( $p<$ 0.001 ) indicated that the sample was suitable for factor analysis.

Following established practice (Byrne 2013; $\mathrm{Hu}$ and Bentler 1999), we used various fit indices to evaluate the fit of the model: $\chi^{2} / d f$ should be less than 3.00, SRMR (Standardized Root-Mean-Square Residual) should be close to 0.08, CFI (Comparative Fit Index) and TLI (Tucker-Lewis Index) should be close to 0.95, and RMSEA (Root Mean Square Error of Approximation) should be close to 0.06 .

In this study, we used item pairs to conduct CFA for higher reliability (Cattell and Burdsal Jr 1975; Kishton and Widaman 1994), normal distribution (Bagozzi and Heatherton 1994) and less idiosyncratic variance (Little et al. 2002). The results of CFA were shown in Table 2. The three-factor model fit the data best compared with two-factor model and one-factor model. This result suggested that hypothesized model of three factors was better than others. Distinctiveness of all scales used in this study was ensured.

\section{Test of hypotheses}

Hypothesis 1 indicated that internal social capital mediates the effect of negative career shocks on focus on opportunities. Table 3 showed the result of indirect effect. For the

Table 1 Descriptive statistics and correlations $(N=210)^{\mathrm{a}}$

\begin{tabular}{|c|c|c|c|c|c|c|c|c|c|c|c|c|c|}
\hline & & Mean & SD & 1 & 2 & 3 & 4 & 5 & 6 & 7 & 8 & 9 & 10 \\
\hline 1 & Gender & 1.69 & 0.47 & 1.00 & & & & & & & & & \\
\hline 2 & Age & 31.28 & 5.44 & -0.01 & 1.00 & & & & & & & & \\
\hline 3 & Tenure & 7.88 & 5.89 & -0.02 & $0.92^{* *}$ & 1.00 & & & & & & & \\
\hline 4 & Education & 3.35 & 1.29 & 0.04 & $0.22^{* *}$ & -0.02 & 1.00 & & & & & & \\
\hline 5 & Company scale & 3.33 & 0.73 & 0.07 & -0.12 & -0.09 & -0.04 & 1.00 & & & & & \\
\hline 6 & Company type & 3.30 & 2.04 & -0.04 & $-0.21^{* *}$ & $-0.15^{*}$ & $-0.25^{* *}$ & 0.11 & 1.00 & & & & \\
\hline 7 & NCS & 0.81 & 0.39 & -0.09 & -0.11 & -0.11 & 0.00 & 0.08 & $0.18^{* *}$ & 1.00 & & & \\
\hline 8 & ISC & 3.47 & 0.82 & -0.06 & -0.10 & -0.09 & -0.11 & -0.05 & 0.13 & $0.19^{* *}$ & 1.00 & & \\
\hline 9 & FTP-O & 3.45 & 0.92 & -0.03 & $-0.23^{* *}$ & $-0.24^{* *}$ & 0.03 & -0.04 & 0.12 & $0.16^{*}$ & $0.27^{* *}$ & 1.00 & \\
\hline 10 & OE & 3.37 & 0.77 & 0.04 & 0.03 & 0.04 & 0.01 & 0.11 & -0.06 & $-0.15^{*}$ & 0.01 & -0.13 & 1.00 \\
\hline
\end{tabular}

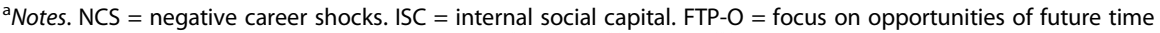
perspective. $\mathrm{OE}=$ organizational embeddedness. ${ }^{*} p<0.05,{ }^{* *} p<0.01,{ }^{* * *} p<0.001$ 
Table 2 CFA of the items $(N=210)$

\begin{tabular}{llllllll}
\hline & $x^{2}$ & $d f$ & $x^{2} / d f$ & SRMR & CFI & TLI & RMSEA \\
\hline CFA-three factors & 39.75 & 24 & 1.66 & 0.05 & 0.96 & 0.94 & 0.06 \\
CFA-two factors & 247.63 & 26 & 9.52 & 0.14 & 0.41 & 0.19 & 0.20 \\
CFA-one factor & 284.64 & 27 & 10.54 & 0.16 & 0.32 & 0.09 & 0.21 \\
\hline
\end{tabular}

total effect, negative shocks can not predict focus on opportunities $(\beta=0.21,95 \% \mathrm{CI}=$ $[-0.002,0.63])$. Internal social capital positively predicted focus on opportunities $(\beta=.27,95 \% \mathrm{CI}=[0.03,0.41])$. The indirect effect of negative shocks on focus on opportunities was significant $(\beta=.10,95 \% \mathrm{CI}=[0.02,0.25])$. The explained variance changed from .06 to .13 . This result indicated that internal social capital mediates the effect of negative career shocks on focus on opportunities. Thus, Hypothesis 1 was supported.

Hypotheses 2 and 3 proposed that organizational embeddedness moderates the strength of the mediated relationship between negative shocks and focus on opportunities through internal social capital. We further conducted the simple slope test to illustrate this result according to Aiken and West (1991). Table 4 showed the moderated mediation results. Fig. 2 depicted the relationship between internal social capital levels and focus on opportunities at both low and high levels of organizational embeddedness. The results showed that when organizational embeddedness was higher (one SD above the mean), the relationship between internal social capital and focus on opportunities was stronger $(\beta=0.16,95 \% \mathrm{CI}=[0.03,0.36])$, and when organizational embeddedness was lower (one SD below the mean), the relationship became non-significant $(\beta=0.03$, $95 \% \mathrm{CI}=[-0.03,0.16])$. Thus the relationship between internal social capital and focus on opportunities is only significant when organizational embeddedness was high. This result provided support for Hypothesis 2 but not for Hypothesis 3.

\section{Discussion}

There has been studies on how career shocks influence voluntary turnover. We examine the effects of career shocks on occupational future time perspective because the study about antecedents of occupational future time perspective is especially rare and the underlying mechanism is not clear. This results support a model in which internal social capital mediates the effect of negative career shocks on the dimension of focus on opportunites. Even negative shocks can not directly predict future time perspective, but they do

Table 3 Regression results for testing mediation in Hypothesis $1^{a}$

\begin{tabular}{lll}
\hline Variable and statistic & Outcome: Internal social capital & Outcome: Focus on opportunities \\
\hline Constant & $3.43^{* * *}$ & $2.86^{* * *}$ \\
Gender & -0.08 & -0.02 \\
Age & 0.02 & -0.02 \\
Tenure & -0.03 & -0.01 \\
Education & -0.15 & 0.10 \\
Negative career shocks & $0.38^{* *}$ & 0.21 \\
Internal social capital & & $0.27^{* * *}$ \\
$F$ & 2.48 & 5.22 \\
$R^{2}$ & 0.06 & 0.13
\end{tabular}

${ }^{a}$ Notes. Bootstrap sample size $=5000$. Results were reported after controlling for age, gender, tenure, education and perceived remaining time. ${ }^{*} p<0.05,{ }^{* *} p<0.01,{ }^{* * *} p<0.001$ 
Table 4 Moderated mediation results for career shocks across levels of organizational embeddedness $^{a}$

\begin{tabular}{llllll}
\hline Moderator & Level & Effect & Boot SE & Boot LLCl & Boot ULCl \\
\hline Organizational embeddedness & -1 SD $(-.77)$ & 0.03 & 0.05 & -0.03 & 0.16 \\
& 0.00 & 0.09 & 0.05 & 0.02 & 0.23 \\
& +1 SD (.77) & 0.16 & 0.08 & 0.03 & 0.36
\end{tabular}

${ }^{\mathrm{a}}$ Notes. Bootstrap sample size $=5000$. Results were reported after controlling for age, gender, tenure, education and perceived remaining time

still relate with focus on opportunities which may help to find other mechanisms in the future. As individuals become more embedded in the organization, this mediation effect would be stronger. However, for people less embedded within their organization, there is no effect. The result could be seen as in line with the previous studies showing that organizational embeddedness could buffer the negative effect of negative shocks (Burton et al. 2010; Holtom et al. 2012).

\section{Implications for theory development}

We obtain a novel result showing that negative career shocks can motivate people to be open for future career development through internal social capital. This positive effect was unexpected since negative career shocks usually generate negative effects such as turnover (Holtom et al. 2005).

This research shows the mechanisms by which negative career shocks motivate individuals to focus on opportunities and under what circumstances this effect exists. We incorporated negative career shocks within a conservation of resources theory framework in response to a calls for the use of this theory to study career shocks (Akkermans et al. 2018). We demonstrate the significance of internal social capital as a mediator of the negative relationship of career shocks to focus on opportunities by using the conservation of resource theory to explain the resource loss and retention.

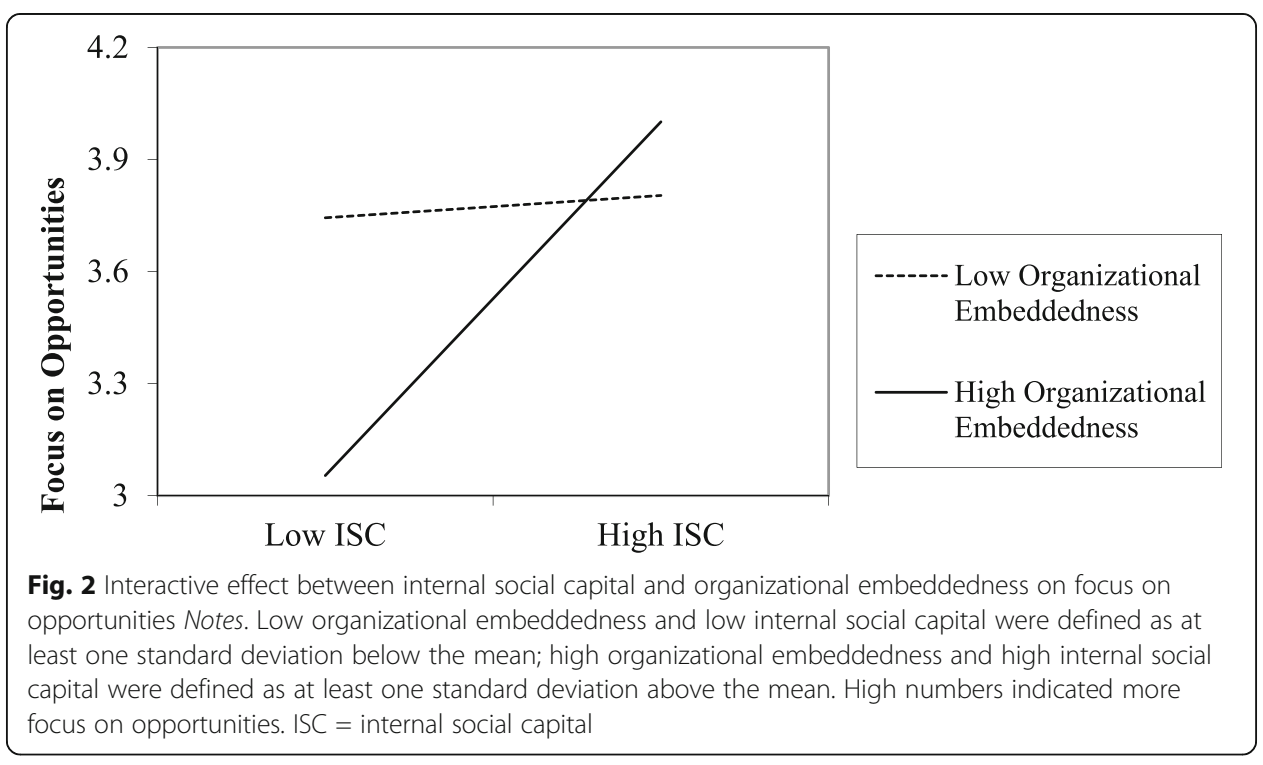


Moreover, while social links are important antecedents of employees' attachment to the current organization (Mitchell et al., 2001), only few studies has examined the role of social links on career shocks. Based on the unfolding model of voluntary employee turnover (Lee and Mitchell 1994; Lee et al. 1996), shocks can alter individuals' psychological processes by recalling prior memories and violating individuals' value image. In this case people would probably choose a preexisting plan to leave. Our result offers a new explanation of the initial process of the unfolding model of voluntary employee turnover and addresses the buffering effect of negative shocks by introducing the role of internal social capital, showing the importance of social capital in the workplace.

Furthermore, organizational embeddedness plays an important role in why people stay, as a supplement to turnover research. It explains a lot of variance in the turnover decision (Hom et al. 2017; Mitchell and Lee 2001). In prior studies, organizational embeddedness has been studied as a moderator or mediator and plays an important role in improving individuals' work outcomes (Lee et al. 2014). Empirical studies have already shown that organizational embeddedness can attenuate shocks' deleterious consequences such as employee turnover and job performance (Burton et al. 2010. Ng and Feldman 2010a, 2010b). Our results show that in terms of individuals' career development, the more they are embedded, the more likely they are to focus on opportunities through internal social capital.

Although researchers recommend studying occupational future time perspective in two separate dimensions, rather than combining into one (Rudolph et al., 2018; Cate and John 2007; Henry et al., 2017), there has been very little research focusing on this construct in detail. We mainly integrate conservation of resources theory and the unfolding model of voluntary employee turnover to analyze how negative career shocks alter employees' occupational future time perspective, especially how negative shocks motivate employees to focus on opportunities. This study shows that as a contextual factor, negative career shocks motivate employees to be optimistic through the influence of social links. The study also expands the research of occupational future time perspective to career studies.

\section{Limitations and future research}

The first limitation is that our research is conducted in Chinese culture. Since China is a highly collectivistic country, relationship or guanxi plays an important role in workplace. Internal social capital and organizational embeddedness both are crucial for employees. This may help to support the effects whereas in other individualist countries this mechanism may not work. Future studies can test this mechanism in other cultures, exploring whether building social relationships is useful for retaining psychological resources. In addition, our study only focuses on internal social capital, while external social capital can also be a supplemental resource to individuals. Based on a perspective within the organization, this study concerns only individuals' internal social capital so as to discuss the moderating effect of organizational embeddedness on the relationship between internal social capital and focus on opportunities. Future studies should be conducted from a different perspective to understand the functions of external social capital in the process of career shocks.

Lee and Mitchell (1994) defined a shock as "an event that generates information or has meaning about a person's job. A shock must be interpreted and integrated into the 
person's system of beliefs and images." In this sense, whether a shock is positive or negative should depend on individuals' perception of it. If a negative career shock could be perceived as a motivating factor, then it is inappropriate to define it as negative. As career shocks matter a lot to employees' turnover intentions or behaviors and company operations, more research should be done to clarify its definition and effects. Career shocks can often "jar an individual into psychological process of reappraising the trajectory of their current career path" (Seibert et al. 2013) or "jar employees toward deliberate judgements about their careers" (Slay et al., 2004). However, we did not discuss the psychological process aroused by negative career shocks and this process may serve as a mediator between negative career shocks and internal social capital. Future studies should take these mechanisms into account to better explain that in what psychological state individuals will conduct social capital development behaviors.

Future research can expand to the whole turnover process to uncover the mechanisms present throughout the process and contribute to our understanding of turnover. Once employees focus on opportunities, they are more likely to have job search behaviors, therefore increasing the likelihood of voluntary turnover.

We collect the second wave data 6 months after the first wave; a two-wave study could avoid common method variance to a certain degree. However, occupational future time perspective is part of an individual's cognition which may not be altered in the short term. Future research can expand the lagging period to at least 1 year, trying to depict the varying picture of occupational future time perspective. For example, future research could follow up individuals' reactions on shocks in different career periods. Another limitation of the study is our use of snowball or chain referral sampling method to collect data, which leads to $91 \%$ of our sample holding a bachelor's degree. Although snowball sampling is often applied when objects are not easily available or the focus of study is on a sensitive issue (Noy 2008), it is obviously a drawback that research results may suffer by relatively greater homogeneity of participants. Highly educated individuals may influence the future time perspective even experiencing the negative shocks, so the result may be difficult to generalize to different kinds of population (Biernacki and Waldorf 1981).

\section{Conclusion}

This research responds to the call for study in career shocks using conservation of resources theory (Akkermans et al. 2018), and separating future time perspective into two separate dimensions (Rudolph et al., 2018; Cate and John 2007; Henry et al., 2017). While negative career shocks may not directly motivate individuals to focus on opportunities, internal social capital could mediate the effect, with highly organizationally embedded employees experiencing this indirect effect more strongly.

\section{Appendix}

Career shocks scale (Seibert et al. 2013)

1. Visible job success. (measuring positive career shocks, not used)

2. Quick raise or promotion. (measuring positive career shocks, not used)

3. Had a mentor or colleague that was important to you leave the company. 
4. Your organization went through a significant negative event such as a reductionin-workforce, bankruptcy, or major ethical scandal.

Items measuring internal social capital from political skill inventory (Ferris et al. 2005)

1. I spend a lot of time and effort at work networking with others.

2. I am good at building relationships with influential people at work.

3. At work, I know a lot of important people and am well connected.

4. I spend a lot of time at work developing connections with others. (not used because of relatively lower loading)

5. I am good at using my connections and network to make things happen at work. (not used because of relatively lower loading)

6. I have developed a large network of colleagues and associates at work whom I can call on for support when I really need to get things done. (not used because of relatively lower loading)

In their paper, Ng and Feldman (2010a, 2010b) used 6 items in Political Skill Inventory (Ferris et al. 2005) to measure internal social capital development behaviors. In this study, we chose three items with higher loadings out of those six items to measure internal social capital.

Global organizational embeddedness scale (Crossley et al. 2007)

1. I feel attached to this organization.

2. It would be difficult for me to leave this organization.

3. I'm too caught up in this organization to leave.

4. I simply could not leave the organization that I work for.

5. It would be easy for me to leave this organization. (reverse coded)

6. I am tightly connected to this organization.

7. I feel tied to this organization. (not used because of semantic repetition)

\section{Occupational future time perspective scale (Zacher and Frese 2009)}

Focus on opportunities:

1. Many opportunities await me in my occupational future

2. I expect that I will set many new goals in my occupational future

3. My occupational future is filled with possibilities

Perceived remaining time:

1. Most of my occupational life lies ahead of me. (reverse coded)

2. My occupational future seems infinite to me. (reverse coded)

3. As I get older, I begin to experience time in my occupational future as limited. (reverse coded) 


\section{Authors' contributions}

In preparing this manuscript, JF and ML worked together to propose the research topic and developed the theoretical model. In addition, JF provided the preliminary research design, conducted the literature review, offered explanation of the hypotheses, collected data and demonstrated the limitations and implications of this study. ML analysed the data. WZ drafted the manuscript and improved the introduction and discussion sections dramatically. SL participated in the discussion of the research model and helped to draft the manuscript, updated the literature and hypotheses development. All authors read and approved the final manuscript.

\section{Funding}

No funding was received.

\section{Availability of data and materials}

The datasets used and/or analysed during the current study are available from the corresponding author on reasonable request.

\section{Competing interests}

The authors declare that they have no competing interests.

Received: 17 July 2019 Accepted: 29 November 2019

- 20.0

\section{References}

Aiken, L. S., \& West, S. G. (1991). Multiple regression: Testing and interpreting interactions. Newbury Park: Sage. https://doi.org/10. 1037/0021-9010.84.6.897.

Akkermans, J., Seibert, S. E., \& Mol, S. T. (2018). Tales of the unexpected: Integrating career shocks in the contemporary careers literature. SA Journal of Industrial Psychology, 44, 1-10. https://doi.org/10.4102/sajip.v44i0.1503.

Avanzi, L., Fraccaroli, F., Castelli, L., Marcionetti, J., Crescentini, A., Balducci, C., \& van Dick, R. (2018). How to mobilize social support against workload and burnout: The role of organizational identification. Teaching and Teacher Education, 69, 154167. https://doi.org/10.1016/.jtate.2017.10.001.

Avanzi, L., Schuh, S. C., Fraccaroli, F., \& van Dick, R. (2015). Why does organizational identification relate to reduced employee burnout? The mediating influence of social support and collective efficacy. Work and Stress, 29(1), 1-10. https://doi.org/ 10.1080/02678373.2015.1004225

Bagozzi, R. P., \& Heatherton, T. F. (1994). A general approach to representing multifaceted personality constructs: Application to state self-esteem. Structural Equation Modeling: A Multidisciplinary Journal, 1(1), 35-67. https://doi.org/10.1080/ 10705519409539961.

Baruch, Y. (2004). Transforming careers: From linear to multidirectional career paths: Organizational and individual perspectives. Career Development International, 9(1), 58-73. https://doi.org/10.1108/13620430410518147.

Baumeister, R. F., Bratslavsky, E., Finkenauer, C., \& Vohs, K. D. (2001). Bad is stronger than good. Review of General Psychology, 5(4), 323-370. https://doi.org/10.1037/1089-2680.5.4.323.

Beach, L. R. (1990). Image theory: Decision making in personal and organizational contexts. Wiley. https://doi.org/10.1002/job. 4030130509.

Betsworth, D. G., \& Hansen, J. I. C. (1996). The categorization of serendipitous career development events. Journal of Career Assessment, 4(1), 91-98. https://doi.org/10.1177/106907279600400106.

Biernacki, P., \& Waldorf, D. (1981). Snowball sampling: Problems and techniques of chain referral sampling. Sociological Methods \& Research, 10 (2), 141-163. https://doi.org/10.1177/004912418101000205.

Bright, J. E., Pryor, R. G., \& Harpham, L. (2005). The role of chance events in career decision making. Journal of Vocational Behavior, 66(3), 561-576. https://doi.org/10.1016/j.jvb.2004.05.001.

Brockner, J. (1992). The escalation of commitment to a failing course of action: Toward theoretical progress. Academy of Management Review, 17(1), 39-61. https://doi.org/10.5465/AMR.1992.4279568.

Burton, J. P., Holtom, B. C., Sablynski, C. J., Mitchell, T. R., \& Lee, T. W. (2010). The buffering effects of job embeddedness on negative shocks. Journal of Vocational Behavior, 76(1), 42-51. https://doi.org/10.1016/j.jvb.2009.06.006.

Byrne, B. M. (2013). Structural equation modeling with Mplus: Basic concepts, applications, and programming. Routledge. https:// doi.org/10.4324/9780203807644.

Carstensen, L. L. (2006). The influence of a sense of time on human development. Science, 312(5782), 1913-1915. https://doi. org/10.1126/science.1127488.

Carstensen, L. L., Isaacowitz, D. M., \& Charles, S. T. (1999). Taking time seriously: A theory of socioemotional selectivity. American Psychologist, 54(3), 165. https://doi.org/10.1037//0003-066X.54.3.165.

Cate, R. A., \& John, O. P. (2007). Testing models of the structure and development of future time perspective: Maintaining a focus on opportunities in middle age. Psychology and Aging, 22 (1), 186-201. https://doi.org/10.1037/0882-7974.22.1.186.

Cattell, R. B., \& Burdsal Jr., C. A. (1975). The radial parcel double factoring design: A solution to the item-vs-parcel controversy. Multivariate Behavioral Research, 10(2), 165-179. https://doi.org/10.1207/s15327906mbr1002_3.

Chen, S., Westman, M., \& Eden, D. (2009). Impact of enhanced resources on anticipatory stress and adjustment to new information technology: A field-experimental test of conservation of resources theory. Journal of Occupational Health Psychology, 14(3), 219-230. https://doi.org/10.1037/a0015282.

Cheng, C., Yang, L., Chen, Y., Zou, H., Su, Y., \& Fan, X. (2016). Attributions, future time perspective and career maturity in nursing undergraduates: Correlational study design. BMC Medical Education, 16 (1),26. https://doi.org/10.1186/s12909016-0552-1.

Collins, N. L., \& Feeney, B. C. (2000). A safe haven: An attachment theory perspective on support seeking and caregiving in intimate relationships. Journal of Personality and Social Psychology, 78(6), 1053-1073. https://doi.org/10.1037/0022-3514.78. 6.1053 . 
Crossley, C. D., Bennett, R. J., Jex, S. M., \& Burnfield, J. L. (2007). Development of a global measure of job embeddedness and integration into a traditional model of voluntary turnover. Journal of Applied Psychology, 92(4), 1031-1042. https://doi.org/ 10.1037/0021-9010.92.4.1031

Diestel, S., \& Schmidt, K. H. (2012). Lagged mediator effects of self-control demands on psychological strain and absenteeism. Journal of Occupational and Organizational Psychology, 85(4), 556-578. https://doi.org/10.1111/j.2044-8325.2012.02058.x.

Ferris, G. R., Treadway, D. C., Kolodinsky, R. W., Hochwarter, W. A., Kacmar, C. J., Douglas, C., \& Frink, D. D. (2005). Development and validation of the political skill inventory. Journal of Management, 31, 126-152. https://doi.org/10.1177/ 0149206304271386.

Forret, M. L., \& Dougherty, T. W. (2004). Networking behaviors and career outcomes: Differences for men and women? Journal of Organizational Behavior, 25, 419-437. https://doi.org/10.2307/4093697.

Frisch, J. U., Häusser, J. A., van Dick, R., \& Mojzisch, A. (2014). Making support work: The interplay between social support and social identity. Journal of Experimental Social Psychology, 55, 154-161. https://doi.org/10.1016/j.jesp.2014.06.009.

Froehlich, D. E., Beausaert, S., \& Segers, M. (2016). Aging and the motivation to stay employable. Journal of Managerial Psychology, 31(3), 756-770. https://doi.org/10.1108/JMP-08-2014-0224.

Fung, H. H., Lai, P., \& Ng, R. (2001). Age differences in social preferences among Taiwanese and mainland Chinese: The role of perceived time. Psychology and Aging, 16(2), 351-356. https://doi.org/10.1037//0882-7974.16.2.351.

Gorgievski, M. J., Halbesleben, J. R., \& Bakker, A. B. (2011). Expanding the boundaries of psychological resource theories. Journal of Occupational and Organizational Psychology, 84, 1-7. https://doi.org/10.1111/j.2044-8325.2010.02015.x.

Granovetter, M. S. (1973). The strength of weak ties. American Journal of Sociology, 78(6), 1360-1380. https://doi.org/10.1086/ 225469.

Halbesleben, J. R. (2010). The role of exhaustion and workarounds in predicting occupational injuries: A cross-lagged panel study of health care professionals. Journal of Occupational Health Psychology, 15(1), 1-16. https://doi.org/10.1037/ a0017634.

Halbesleben, J. R., \& Wheeler, A. R. (2011). I owe you one: Coworker reciprocity as a moderator of the day-level exhaustion-performance relationship. Journal of Organizational Behavior, 32, 608-626. https://doi.org/10.1002/ job.748.

Henry, H., Zacher, H., \& Desmette, D. (2017). Future time perspective in the work context: a systematic review of quantitative studies. Frontiers in Psychology, 8, Article 413. https://doi.org/10.3389/fpsyg.2017.00413.

Hirschi, A. (2010). The role of chance events in the school-to-work transition: The influence of demographic, personality and career development variables. Journal of Vocational Behavior, 77, 39-49. https://doi.org/10.1016/j.jvb.2010.02.002.

Hobfoll, S. E. (1988). The ecology of stress. Washington, DC: Hemisphere Publishing Corp.

Hobfoll, S. E. (1989). Conservation of resources: A new attempt at conceptualizing stress. American Psychologist, 44(3), 513524. https://doi.org/10.1037/0003-066X.44.3.513.

Holtom, B. C., Burton, J. P., \& Crossley, C. D. (2012). How negative affectivity moderates the relationship between shocks, embeddedness and worker behaviors. Journal of Vocational Behavior, 80(2), 434-443. https://doi.org/10. 1016/j.jvb.2011.12.006.

Holtom, B. C., \& Inderrieden, E. J. (2006). Integrating the unfolding model and job embeddedness model to better understand voluntary turnover. Journal of Managerial Issues, 18, 435-452. http://ink.galegroup.com/apps/doc/ A158388761/GPS? U=wash_main\&sid=GPS\&xid=d427ed31.

Holtom, B. C., Mitchell, T. R., Lee, T. W., \& Inderrieden, E. J. (2005). Shocks as causes of turnover: What they are and how organizations can manage them. Human Resource Management, 44, 337-352. https://doi.org/10.1002/hrm.20074.

Hom, P. W., Lee, T. W., Shaw, J. D., \& Hausknecht, J. P. (2017). One hundred years of employee turnover theory and research. Journal of Applied Psychology, 102(3), 530-545. https://doi.org/10.1037/apl0000103.

$\mathrm{Hu}$, L., \& Bentler, P. M. (1999). Cutoff criteria for fit indexes in covariance structure analysis: Conventional criteria versus new alternatives. Structural Equation Modeling, 6(1), 1-55. https://doi.org/10.1080/10705519909540118.

Kishton, J. M., \& Widaman, K. F. (1994). Unidimensional versus domain representative parceling of questionnaire items: An empirical example. Educational and Psychological Measurement, 54(3), 757-765. https://doi.org/10.1177/ 0013164494054003022.

Kooij, D. T., Kanfer, R., Betts, M., \& Rudolph, C. W. (2018). Future time perspective: A systematic review and meta-analysis. Journal of Applied Psychology, 103(8), 867-893. https://doi.org/10.1037/apl0000306.

Kooij, D. T. A. M., Bal, P. M., \& Kanfer, R. (2014). Future time perspective and promotion focus as determinants of intraindividual change in work motivation. Psychology and Aging, 29, 319-328. https://doi.org/10.1037/a0036768.

Koopmann, J., Lanaj, K., Bono, J., \& Campana, K. (2016). Daily shifts in regulatory focus: The influence of work events and implications for employee well-being. Journal of Organizational Behavior, 37(8), 1293-1316. https:/doi.org/10.1002/job.2105.

Lang, F. R., \& Carstensen, L. L. (2002). Time counts: Future time perspective, goals, and social relationships. Psychology and Aging, 17, 125. https://doi.org/10.1037/0882-7974.17.1.125.

Larsen, R. J., \& Ketelaar, T. (1991). Personality and susceptibility to positive and negative emotional states. Journal of Personality and Social Psychology, 61, 132-140. https://doi.org/10.1037/0022-3514.61.1.132.

Lee, E. S., Park, T. Y., \& Koo, B. (2015). Identifying organizational identification as a basis for attitudes and behaviors: A metaanalytic review. Psychological Bulletin, 141(5), 1049-1080. https://doi.org/10.1037/bul0000012.

Lee, T. W., Burch, T. C., \& Mitchell, T. R. (2014). The story of why we stay: A review of job embeddedness. Annual Review of Organizational Psychology and Organizational Behavior, 1, 199-216. https://doi.org/10.1146/annurevorgpsych-031413-091244.

Lee, T. W., Hom, P. W., Eberly, M. B., Li, J. J., \& Mitchell, T. R. (2017). On the next decade of research in voluntary employee turnover. Academy of Management Perspectives, 31, 201-221. https://doi.org/10.5465/amp.2016.0123.

Lee, T. W., \& Mitchell, T. R. (1994). An alternative approach: The unfolding model of voluntary employee turnover. Academy of Management Review, 19, 51-89. https://doi.org/10.5465/amr.1994.9410122008.

Lee, T. W., Mitchell, T. R., Wise, L., \& Fireman, S. (1996). An unfolding model of voluntary employee turnover. Academy of Management Journal, 39, 5-36. https://doi.org/10.5465/256629.

Little, T. D., Cunningham, W. A., Shahar, G., \& Widaman, K. F. (2002). To parcel or not to parcel: Exploring the question, weighing the merits. Structural Equation Modeling, 9(2), 151-173. https://doi.org/10.1207/S15328007SEM0902_1. 
Liu, J., Kwan, H. K., Fu, P. P., \& Mao, Y. (2013). Ethical leadership and job performance in China: The roles of workplace friendships and traditionality. Journal of Occupational and Organizational Psychology, 86, 564-584. https://doi.org/10.1111/joop.12027.

Marsden, P. V., \& Hurlbert, J. S. (1988). Social resources and mobility outcomes: A replication and extension. Social Forces, 66(4), 1038-1059. https://doi.org/10.1093/sf/66.4.1038.

Miller, M. J. (1983). The role of happenstance in career choice. Vocational Guidance Quarterly, 32, 16-20. https://doi.org/10. 1002/j.2164-585X.1983.tb01552.x.

Mitchell, T. R., Holtom, B. C., Lee, T. W., Sablynski, C. J., \& Erez, M. (2001). Why people stay: Using job embeddedness to predict voluntary turnover. Academy of Management Journal, 44(6), 1102-1121. https://doi.org/10.5465/3069391.

Mitchell, T. R., \& Lee, T. W. (2001). The unfolding model of voluntary turnover and job embeddedness: Foundations for a comprehensive theory of attachment. Research in Organizational Behavior, 23, 189-246. https://doi.org/10.1016/S0191 3085(01)23006-8.

Ng, T. W., \& Feldman, D. C. (2010a). The effects of organizational embeddedness on development of social capital and human capital. Journal of Applied Psychology, 95(4), 696-712. https://doi.org/10.1037/a0019150.

Ng, T. W., \& Feldman, D. C. (2010b). The impact of job embeddedness on innovation-related behaviors. Human Resource Management, 49(6), 1067-1087. https://doi.org/10.1002/hrm.20390.

Ng, T. W. H., \& Feldman, D. C. (2007). Organizational embeddedness and occupational embeddedness across career stages. Journal of Vocational Behavior, 70(2), https://doi.org/10.1016/j.jvb.2006.10.002.

Noy, C. (2008). Sampling knowledge: The hermeneutics of snowball sampling in qualitative research. International Journal of Social Research Methodology, 11(4), 327-344. https://doi.org/10.1080/13645570701401305.

Park, I. J., \& Jung, H. (2015). Relationships among future time perspective, career and organizational commitment, occupational self-efficacy, and turnover intention. Social Behavior and Personality: An International Journal, 43(9), 15471561. https://doi.org/10.2224/sbp.2015.43.9.1547.

Pearlin, L. I., Menaghan, E. G., Lieberman, M. A., \& Mullan, J. T. (1981). The stress process. Journal of Health and Social Behavior, 22(4), 337-356. https://doi.org/10.2307/2136676.

Petriglieri, J. L. (2011). Under threat: Responses to and the consequences of threats to individuals' identities. Academy of Management Review, 36(4), 641-662. https://doi.org/10.5465/amr.2009.0087.

Pfeffer, J. (1992). Managing with power. Boston: Harvard Business School Press.

Preacher, K. J., \& Hayes, A. F. (2004). SPSS and SAS procedures for estimating indirect effects in simple mediation models. Behavior Research Methods, Instruments, \& Computers, 36(4), 717-731. https://doi.org/10.3758/BF03206553.

Rudolph, C. W., Kooij, D. T., Rauvola, R. S., \& Zacher, H. (2018). Occupational future time perspective: A meta-analysis of antecedents and outcomes. Journal of Organizational Behavior, 39(2), 229-248. https://doi.org/10.1002/job.2264.

Seibert, S. E., Kraimer, M. L., Holtom, B. C., \& Pierotti, A. J. (2013). Even the best laid plans sometimes go askew: Career selfmanagement processes, career shocks, and the decision to pursue graduate education. Journal of Applied Psychology, 98 (1), 169-182. https://doi.org/10.1037/a0030882.

Seibert, S. E., Kraimer, M. L., \& Liden, R. C. (2001). A social capital theory of career success. Academy of Management Journal, 44, 219-237. https://doi.org/10.2307/3069452.

Selenko, E., Mäkikangas, A.r Mauno, S., \& Kinnunen, U. (2013). How does job insecurity relate to self-reported job performance? Analysing curvilinear associations in a longitudinal sample. Journal of Occupational and Organizational Psychology, 86, 522-542. https://doi.org/10.1111/joop.12020.

Seta, J. J., Haire, A., \& Seta, C. E. (2008). Averaging and summation: Positivity and choice as a function of the number and affective intensity of life events. Journal of Experimental Social Psychology, 44(2), 173-186. https://doi.org/10.1016/j.jesp. 2007.03.003.

Slay, H. S., Taylor, M. S., \& Williamson, I. O. (2004). Midlife transition decision processes and career success: The role of identity, networks, and shocks. Austin: In annual meeting of the Academy of Human Resource Development http://citeseerx.ist.psu. edu/viewdoc/download?doi=10.1.1.574.1046\&rep=rep1\&type=pdf.

Staw, B. M. (1981). The escalation of commitment to a course of action. Academy of Management Review, 6(4), 577-587. https://doi.org/10.2307/257636.

Taber, B. J., \& Blankemeyer, M. S. (2015). Time perspective and vocational identity statuses of emerging adults. The Career Development Quarterly, 63(2), 113-125. https://doi.org/10.1002/cdq.12008.

Van Dick, R., Christ, O., Stellmacher, J., Wagner, U., Ahlswede, O., Grubba, C., et al. (2004). Should I stay or should I go? Explaining turnover intentions with organizational identification and job satisfaction. British Journal of Management, 15(4), 351-360. https://doi.org/10.1111/j.1467-8551.2004.00424.x.

Vuori, V., \& Okkonen, J. (2012). Knowledge sharing motivational factors of using an intra-organizational social media platform. Journal of Knowledge Management, 16(4), 592-603. https://doi.org/10.1108/13673271211246167.

Wayne, S. J., Liden, R. C., Kraimer, M. L., \& Graf, I. K. (1999). The role of human capital, motivation, and supervisor sponsorship in predicting career success. Journal of Organizational Behavior, 20(5), 577-595. https://doi.org/10.2307/3100430.

Weikamp, J. G., \& Göritz, A. S. (2016). Organizational citizenship behavior and job satisfaction: The impact of occupational future time perspective. Human Relations, 69(11), 2091-2115. https://doi.org/10.1177/0018726716633512.

Weiss, H. M., \& Cropanzano, R. (1996). Affective events theory: A theoretical discussion of the structure, causes and consequences of affective experiences at work. Research in Organizational Behavior, 18, 1-74.

Wijayanto, B. R., \& Kismono, G. (2004). The effect of job embeddedness on organizational citizenship behavior: The mediating role of sense of responsibility. Gadjah Mada International Journal of Business, 6(3), 335-354. https://doi.org/10.22146/ gamaijb.5554.

Xanthopoulou, D., Bakker, A. B., Demerouti, E., \& Schaufeli, W. B. (2009). Work engagement and financial returns: A diary study on the role of job and personal resources. Journal of Occupational and Organizational Psychology, 82, 183-200. https:// doi.org/10.1348/096317908X285633.

Zacher, H., \& de Lange, A. H. (2011). Relations between chronic regulatory focus and future time perspective: Results of a cross-lagged structural equation model. Personality and Individual Differences, 50(8), 1255-1260. https://doi.org/10.1016/j. paid.2011.02.020.

Zacher, H., \& Frese, M. (2009). Remaining time and opportunities at work: Relationships between age, work characteristics, and occupational future time perspective. Psychology and Aging, 24(2), 487-493. https://doi.org/10.1037/a0015425. 
Zacher, H., \& Frese, M. (2011). Maintaining a focus on opportunities at work: The interplay between age, job complexity, and the use of selection, optimization, and compensation strategies. Journal of Organizational Behavior, 32(2), 291-318. https://doi.org/10.1002/job.683

Zimmerman, B. K., Dormann, C., \& Dollard, M. F. (2011). On the positive aspects of customers: Customer-initiated support and affective crossover in employee-customer dyads. Journal of Occupational and Organizational Psychology, 84(1), 31-57. https://doi.org/10.1111/j.2044-8325.2010.02011.x

Zippay, A. (2001). The roles of social capital in reclaiming human capital: A Longitudinal study of occupational mobility among displaces steelworkers. Journal of Sociology and Social Welfare, 28, 99.

\section{Publisher's Note}

Springer Nature remains neutral with regard to jurisdictional claims in published maps and institutional affiliations.

Submit your manuscript to a SpringerOpen ${ }^{\odot}$ journal and benefit from:

- Convenient online submission

- Rigorous peer review

- Open access: articles freely available online

- High visibility within the field

- Retaining the copyright to your article

Submit your next manuscript at $\boldsymbol{\nabla}$ springeropen.com 